\title{
ANALISIS IMPLEMENTASI PSAP NO.07 TENTANG AKUNTANSI ASET TETAP PADA BALAI PENYANTUNAN LANJUT USIA "SENJA CERAH"
}

\author{
Misye Nikijuluw ${ }^{1}$, Jantje Tinangon ${ }^{2}$, Heince Wokas $^{3}$ \\ ${ }^{1}$ Jurusan Akuntansi, Fakultas Ekonomi dan Bisnis, Universitas Sam Ratulangi, J1.Kampus Bahu, Manado, \\ 95115, Indonesia \\ ${ }^{2}$ Jurusan Akuntansi, Fakultas Ekonomi dan Bisnis, Universitas Sam Ratulangi, Jl.Kampus Bahu, Manado, \\ 95115, Indonesia \\ ${ }^{3}$ Jurusan Akuntansi, Fakultas Ekonomi dan Bisnis, Universitas Sam Ratulangi, Jl.Kampus Bahu, Manado, \\ 95115, Indonesia
}

Email : nmisye@gmail.com

\begin{abstract}
Goverment Accounting Standards (PSAP) No. 07 is the standard for accounting of fied assets in order to generate reliable information in the financial statements. The purpose of this study is to determine whether or not the implementation of PSAP No. 07 is appropriate. The center for advanced arrangement of brightness in inventory cards,transactions, and financial statements. Method used is descriptive.Results show BPLU "Senjah Cerah" that the classification of disclosure is appropriate and disposal, fixed assets with after acquisition depreciates with PSAP No. 07 but it should be an actual fied assets value not
\end{abstract}

Keywords : PSAP 07, Fixed Assets

\section{PENDAHULUAN}

Dalam upaya mewujudkan pemerintah yang transparan dan akuntabel dibutuhkan adanya satu jaminan bahwa segala aktiviktas dan transaksi pemerintah terekam secara baik dengan ukuran - ukuran yang jelas dan dapat diikhtisarkan melalui proses akuntansi dalam bentuk laporan, sehingga bisa dilihat segala yang terjadi dan yang terdapat dalam ruang entitas pemerintah tersebut.

Peraturan Pemerintah Nomor 71 Tahun 2010 tentang Standar Akuntansi Pemerintahan terbit pada bulan Oktober 2010.Lampiran I menjelaskan tentang Standar Akuntansi Pemerintahan Berbasis Akrual dan pada lampiran II menjelaskan tentang Standar Akuntansi Pemerintahan Berbasis Kas Menuju Akrual.Sebelumnya pemerintah telah menetapkan Peraturan Pemerintah Nomor 24 Tahun 2005 tentang Standar Akuntansi Pemerintahan yang berbasis kas. Peraturan ini masih bersifat sementara karena selama pengakuan dan pengukuran pendapatan dan belanja berbasis akrual belum dilaksanakan, digunakanlah pengakuan dan pengukuran berbasis kas, tapi pada Peraturan Pemerintah Nomor 71 Tahun 2010 Bab III Ketentuan Penutup dijelaskan bahwa Peraturan Pemerintah Nomor 24 Tahun 2005 dicabut dan dinyatakan tidak berlaku.

Aset tetap menurut PSAP 07 adalah aset berwujud yang mempunyai masa manfaat lebih dari 12 (dua belas) bulanuntuk digunakan, atau dimaksudkan untuk digunakan, dalam kegiatan pemerintahatau dimanfaatkan oleh masyarakat umum. Aset tetap terdiri dari: a) Tanah; b)Peralatan dan mesin; c) Gedung dan bangunan; d) Jalan, irigasi, dan jaringan; e) Asettetap lainnya; dan f) Konstruksi dalam pengerjaan. Junaidi (2015) dalam Jurnal NeO-Bis menjelaskan bahwa aset tetap adalah aset yang digunakan dalam operasi desa dan manfaatnya dapat dirasakan lebih dari satu tahun.Pengakuan aset tetap dalam instansi maupunsatuan kerja (satker) pemerintahan sebagaimana diatur dalam PSAP 07, harus memenuhi kriteria sebagai berikut: (1) Berwujud; (2) Mempunyai masa manfaat lebih dari 12 (dua belas) bulan; (3) Biaya perolehan aset dapat diukur secara andal; (4) Tidak dimaksudkan untuk dijual dalam operasi normal entitas; dan (5) Diperoleh atau dibangun dengan maksud untuk digunakan. 
Akuntansi aset tetap merupakan salah satu bentuk dari pengelolan barang milik negara.Pengelolaan barang milik negara/daerah diatur dalam Peraturan Pemerintah Nomor 6 Tahun2006.Peraturan Pemerintah tersebut mendefinisikan Barang Milik Negara sebagai "semua barang yangdibeli atau diperoleh atas beban APBN atau berasal dari perolehan lainnya yang sah."Pengelola barang adalah pejabat yang berwenang dan bertanggungjawab menetapkankebijakan dan pedoman serta melakukan pengelolaan Barang Milik Negara/Daerah.Pengguna barang adalah pejabat pemegang kewenangan penggunaan Barang MilikNegara/Daerah.Tujuan PSAP 07 adalah mengatur perlakuan akuntansi untuk aset tetap karena pada kenyataannya banyak masalah yang dihadapi pada pelaksanaan akuntansi aset tetap ini.Masalah yang sering ditemui dalam akuntansi aset tetap adalah pada saat pengakuan aset, perlakuan akuntansi atas penilaian kembali dan penurunan nilai tercatat aset tetap (penyusutan).

Balai Penyantunan Lanjut Usia "Senja Cerah" merupakan salah satu Unit Pelayanan Teknis Dinas dari Dinas Sosial Provinsi Sulawesi Utara yang mempunyai tugas yaitu melaksanakan kegiatan teknis operasional secara langsung berhubungan dengan masyarakat dan teknis penunjang untuk melaksanakan kegiatan dalam rangka mendukung pelaksanaan tugas dinas. Dinas daerah mempunyai tugas untuk melaksanakan kewenangan otonomi daerah kabupaten dalam rangka pelaksanaan tugas desentralisasi yaitu mengatur dan mengurus urusan pemerintahan. Salah satu tugas Balai Penyantunan Lanjut Usia "Senja Cerah" yang berhubungan dengan masyarakat yaitu memberikan bimbingan dan pelayanan bagi lanjut usia terlantar agar dapat hidup baik dan terawat. Balai Penyantunan Lanjut Usia "Senja Cerah" sebagai pelaksana anggaran, harus membuat laporan pertanggungjawaban atas kewenangan yang dilaksanakannya sesuai dengan Peraturan Pemerintah Nomor 71 Tahun 2010 tentang Standar Akuntansi Pemerintahan.

\section{TINJAUAN PUSTAKA}

\subsection{Konsep Akuntansi Pemerintahan}

Sitorus (2015) menyatakan akuntansi pemerintahan merupakan suatu proses sistematik pengelolaan keuangan pemerintah mulai dari bukti transaksi sampai ke proses pelaporan keuangan serta pertanggungjawaban kepada publik. Materi Pelatihan Akuntansi Keuangan Pemerintah Daerah dan SKPD (2014:9) menjelaskan tentang konsep dasar akuntansi pemerintahan sebagai berikut.

1. Lingkungan Akuntansi Pemerintahan

2. Peran Laporan Keuangan

3. Tujuan Pelaporan Keuangan

\subsection{Konsep Standar Akuntansi Pemerintah}

PP Nomor 71 Tahun 2010 tentang Standar Akuntansi Pemerintahan (SAP) menyatakan bahwa SAP adalah prinsip-prinsip akuntansi yang diterapkan dalam menyussun dan menyajikan laporan keuangan pemerintah. PP 71 Tahun 2010 tentang Standar Akuntansi Pemerintahan terdapat 3 (tiga) Lampiran yaitu: Lampiran I tentang Standar Akuntansi Pemerintahan Berbasis Akrual; Lampiran II tentang Standar Akuntansi Pemerintahan Berbasis Kas Menuju Akrual; dan Lampiran III tentang Proses Penyusunan Standar Akuntansi Pemerintahan Berbasis Akrual.SAP Berbasis Akrual diterapkan dalam lingkungan pemerintah yaitu pemerintah pusat, pemerintah daerah dan satuan organisasi di lingkungan pemerintah pusat/daerah, jika menurut peraturan perundang-undangan satuan organisasi dimaksud wajib menyajikan laporan keuangan (Langelo, 2015).

\subsection{Akuntansi Aset Tetap}

Peraturan Pemerintah Nomor 71 Tahun 2010 menyatakan aset adalah sumber daya ekonomiyang dikuasai dan/atau dimiliki oleh pemerintah sebagai akibat dari peristiwa masa lalu dan dari mana manfaat ekonomi dan/atau sosial di masa depan diharapkan dapat diperoleh, baik oleh pemerintah maupun masyarakat, serta dapat diukur dalam satuan uang, 
termasuk sumber daya nonkeuangan yang diperlukan untuk penyediaan jasa bagi masyarakat umum dan sumber-sumber daya yang dipelihara karena alasan sejarah dan budaya.Hanis, et al. (2010) menyatakan pemerintah memiliki kecenderungan untuk membeli daripada menyewa sehingga mereka mengakumulasikan gedung perkantoran, tanah, fasilitas, dan berbagai jenis bangunan umum. Aset menggambarkan kekayaan daerah yang berupa infrastruktur serta sarana dan prasarana daerah (Imawan, 2014).

\subsection{Pengertian Aset Tetap}

Aset tetap merupakan salah satu unsur yang harus dikelola dengan baik agar menghasilkan informasi yang andal dalam laporan keuangan daerah (Kolinug, 2015). Aset tetap adalah aset yang memiliki wujud fisik dan memberikan manfaat ekonomi kepada entitas bisnis selama lebih dari satu periode akuntansi pada masa-masa yang akan datang (Purba, 2013:2).Aset tetap dapat diperoleh dengan berbagai cara seperti pembelian, pertukaran, leasing, pembangunan sendiri dan hibah (Kirana, 2013). Reeve, et al. (2012:2) menjelaskan bahwa aset tetap (fixed asset) adalah aset yang bersifat jangka panjang atau secara relatif memiliki sifat permanen serta dapat digunakan dalam jangka panjang. Aset tetap berwujud merupakan aset dalam bentuk materi yang dimiliki oleh entitas yang akan digunakan dalam produksi dan operasi bisnis sesuai dengan peraturan yang berlaku (Pham, 2014).

\section{METODE PENELITIAN}

\subsection{Jenis dan Sumber Data}

Penelitian ini menggunakanpenelitian deskriptif.Widi (2010:84) menjelaskan bahwa penelitian deskriptif adalah suatu metode penelitian yang menggambarkan semua data atau keadaan subyek/obyek penelitian kemudian dianalisis dan dibandingkan berdasarkan kenyataan yang sedang berlangsung pada saat ini dan selanjutnya mencoba untuk memberikan pemecahan masalahnya.Peneliti menggunakan penelitian deskriptif karena ingin menganalisis serta membandingkan penerapan perlakuan akuntansi aset tetap pada Balai Penyantunan Lanjut Usia "Senja Cerah" dengan PSAP No. 07.

\subsection{Metode Analisis}

Sugiyono (2011:21) menjelaskan bahwa metode analisis adalah metode yang digunakan untuk menggambarkan dan menganalisis suatu hasil penelitian tetapi tidak digunakan untuk membuat kesimpulan yang lebih luas.Metode analisis yang digunakan dalam penelitian ini adalah metode analisis deskriptif yaitu suatu metode pembahasan permasalahan yang sifatnya menguraikan, menggambarkan, membandingkan, dan menerangkan suatu data.Analisis data dilakukan dengan cara sebagai berikut.

a. Mengumpulkan data, mempelajari sejarah, struktur organisasi dan tupoksi, peraturanperaturan dan kebijakan aset tetap yang berlaku, pengakuan aset tetap, pengukuran/penilaian aset tetap, pengeluaran setelah perolehan aset tetap, penyusutan aset tetap, penghentian dan pelepasan aset tetap, serta pengungkapan aset tetap pada Balai Penyantunan Lanjut Usia "Senja Cerah".

b. Membandingkan hasil yang diperoleh dengan literatur yang berhubungan dengan penelitian untuk dijadikan dasar acuan dalam kelengkapan dokumen sumber. Peneliti mencoba untuk mengkaji berdasarkan Pernyataan Standar Akuntansi Pemerintahan (PSAP) No. 07 tentang Akuntansi Aset Tetap.

c. Menarik kesimpulan.

\section{HASIL PENELITIAN DAN PEMBAHASAN}

\subsection{Hasil Analisis}

Kebijakan akuntansi yang berlaku di Balai Penyantunan Lanjut Usia (BPLU) "Senja Cerah" mengacu pada Peraturan Gubernur Sulawesi Utara Nomor 30 Tahun 2014 tentang 
Kebijakan Akuntansi Pemerintah Provinsi Sulawesi Utara. Penyusunan Laporan Keuangan untuk tahun yang berakhir tanggal 31 Desember 2015 berdasarkan asumsi bahwa:

a. SKPD Balai Penyantunan Lanjut Usia "Senja Cerah" Pemerintah Provinsi Sulawesi Utara merupakan organisasi yang mandiri dan menjadi pusat pertanggungjawaban yang harus bertanggungjawab atas pelaksanaan tugasnya sesuai dengan peraturan perundang-undangan yang berlaku atau sebagai entitas pelaporan.

b. Setiap kejadian atau transaksi yang disajikan dalam laporan keuangan dapat dinilai dengan satuan uang, berdasarkan asumsi keterukuran dalam satuan mata uang.

Laporan Keuangan SKPD Balai Penyantunan Lanjut Usia "Senja Cerah" Pemerintah Provinsi Sulawesi Utara Tahun Anggaran 2015 disusun mengacu pada Standar Akuntansi Pemerintah (PP 71 Tahun 2010).Basis akuntansi yang digunakan dalam laporan keuangan SKPD Balai Penyantunan Lanjut Usia "Senja Cerah" Pemerintah Provinsi Sulawesi Utara adalah basis kas untuk pengakuan pendapatan LRA, belanja, dan pembiayaan dalam Laporan Realisasi Anggaran, Laporan Arus Kas dan basis akrual untuk pengakuan pendapatan LO, beban dalam Laporan Operasional serta aset, kewajiban, dan ekuitas dalam Neraca. Basis Kas untuk Laporan Realisasi Anggaran berarti bahwa pendapatan diakui pada saat diterima di Rekening Kas Daerah oleh entitas pelaporan, dan belanja diakui pada saat kas dikeluarkan dari Rekening Kas Daerah atau entitas pelaporan.Basis akrual untuk Neraca berarti bahwa aset, kewajiban, ekuitas dan untuk Laporan Operasional berarti bahwa pendapatan LO, beban diakui dan dicatat pada saat terjadinya transaksi, atau pada saat kejadian atau kondisi lingkungan berpengaruh pada keuangan pemerintah, tanpa memperhatikan saat kas atau setara kas diterima atau dibayar.Periode akuntansi Balai Penyantunan Lanjut Usia "Senja Cerah" untuk penyajian laporan keuangan adalah satu tahun yaitu 1 Januari s/d 31 Desember.

Aset tetap pada Balai Penyantunan Lanjut Usia "Senja Cerah" memiliki pengertian yang sama dengan pengertian aset tetap dalam Pernyataan Standar Akuntansi Pemerintahan (PSAP) Nomor 07, yaitu aset berwujud yang mempunyai masa manfaat lebih dari 12 (dua belas) bulan untuk digunakan dalam kegiatan pemerintah daerah atau dimanfaatkan oleh masyarakat umum.

\section{Pengakuan Aset Tetap}

Aset pada Balai Penyantunan Lanjut Usia (BPLU) "Senja Cerah" diakui sebagai aset tetap jika aset tersebut mempunyai masa manfaat lebih dari 12 (dua belas) bulan, biaya perolehan dapat diukur secara andal, tidak untuk dijual, dan diperoleh untuk digunakan.Aset tetap harus disertai dengan berita acara serah terima sebagai tanda penyerahan hak kepemilikan/penguasaan aset tetap untuk mendukung keandalan pengakuan aset tetap.Berita acara serah terima aset tetap tersebut menandakan pihak Balai Penyantunan Lanjut Usia "Senja Cerah" sudah berhak menggunakan dan mengelola aset tetap yang telah diserahkan.

\section{Pengukuran/Penilaian Aset Tetap}

Aset tetap pada Balai Penyantunan Lanjut Usia "Senja Cerah" dinilai dengan biaya perolehan, apabila penilaian aset tetap dengan menggunakan biaya perolehan tidak memungkinkan maka nilai aset tetap didasarkan pada nilai wajar pada saat perolehan.Berdasarkan hasil wawancara dengan Pengurus Barang, biaya perolehan aset tetap Balai Penyantunan Lanjut Usia "Senja Cerah" terdiri dari keseluruhan biaya yang dikeluarkan untuk perolehan aset tetap sampai siap pakai, tetapi untuk tanah, gedung dan bangunan diukur dengan nilai penyerahan aset tetap tersebut ke pihak Balai Penyantunan Lanjut Usia "Senja Cerah".

\section{Pengeluaran Setelah Perolehan (Subsquent Expenditure)}

Balai Penyantunan Lanjut Usia "Senja Cerah" Pemerintah Provinsi Sulawesi Utara hingga saat ini belum ada pengeluaran setelah perolehan yang dikapitalisasi pada aset tetap 
yang bersangkutan.Pengeluaran-pengeluaran yang terjadi adalah pengeluaran yang tidak memperpanjang masa manfaat aset yang diperlakukan sebagai beban dan disajikan di Laporan Operasional (LO).

\section{Penyusutan Aset Tetap}

Berdasarkan Catatan atas Laporan Keuangan oleh Balai Penyantunan Lanjut Usia "Senja Cerah" Tahun 2016, metode penyusutan yang digunakan oleh adalah Metode Garis Lurus (Straight Line Method). Metode ini adalah metode penyusutan dimana besarnya penyusutan selalu sama dari tiap periode akuntansi selama umur ekonomis dari aset tetap yang bersangkutan.

\section{Penghentian dan Pelepasan Aset Tetap}

Aset tetap akan dilepaskan atau dihapuskan jika sudah tidak bisa mendatangkan manfaat bagi Balai Penyantunan Lanjut Usia (BPLU) "Senja Cerah" Provinsi Sulawesi Utara.Penghapusan meliputi penghapusan dari daftar pengguna dan atau kuasa penganggaran, dan penghapusan dari daftar Barang Milik Daerah

\section{Pengungkapan Aset Tetap}

Balai Penyantunan Lanjut Usia "Senja Cerah" Pemerintah Provinsi Sulawesi Utara mengungkapkan kebijakan akuntansi yang berlaku serta informasi mengenai pos-pos aset tetap dalam Catatan atas Laporan Keuangan (CaLK).Pengungkapan ini sangat penting sebagai penjelasan tentang hal-hal penting yang tercantum dalam neraca.

\section{KESIMPULAN DAN SARAN \\ 5.1 Kesimpulan}

Berdasarkan hasil penelitian dan pembahasan yang dilakukan dalam menganalisis penerapan Pernyataan Standar Akuntansi Pemerintahan (PSAP) No. 07 tentang akuntansi aset tetap pada Balai Penyantunan Lanjut Usia (BPLU) "Senja Cerah" Pemerintah Provinsi Sulawesi Utara, maka dapat diambil kesimpulan yaitu:

Pengklasifikasian, Pengakuan, Pengukuran/Penilaian

Pengeluaran Setelah Perolehan, Penyusutan,Penghentian dan Pelepasan,

Pengungkapan aset tetap BPLU "Senja Cerah" Pemerintah Provinsi Sulawesi Utara pada Catatan atas Laporan Keuangan sudah sesuai dengan PSAP No. 07 yaitu mengungkapkan dasar penilaian yang digunakan untuk menentukan nilai tercatat dalam laporan keuangan.

\subsection{Saran}

Balai Penyantunan Lanjut Usia (BPLU) "Senja Cerah" Pemerintah Provinsi Sulawesi Utara sebaiknya melakukan penyusutan yang sebenarnya dalam laporan keuangan dan Pemerintah Daerah Provinsi Sulawesi Utara segera menetapkan peraturan penyusutan atas aset tetap serta pedomannya agar tercapai keseragaman antar Satuan Kerja Perangkat Daerah (SKPD) di Provinsi Sulawesi Utara sehingga dapat menghasilkan laporan keuangan yang dapat diandalkan.

\section{DAFTAR PUSTAKA}

Auliana, 2014.Analisis Akuntansi Aset Tetap Pada Badan Penanggulangan Bencana Daerah Kota Tanjungpinang Berdasarkan Pernyataan Standar Akuntansi Pemerintahan No 07. Skripsi (tidak dipublikasikan). Fakultas Ekonomi. Universitas Maritim Raja Ali Haji: Tanjungpinang.

Elsye, R., Suwanda, D., Muchidin, U., 2016. Dasar-Dasar Akuntansi Akrual Pemerintah Daerah. Cetakan Pertama. Penerbit Ghalia Indonesia: Bogor.

Kolinug, M., Ilat, V., Pinatik, S., 2015.Analisis Pengelolaan Aset Tetap Pada Dinas Pendapatan Pengelolaan Keuangan dan Aset Daerah Kota Tomohon.Volume 3.Nomor 1. Jurnal EMBA. FEB UNSRAT: Manado. 
Manossoh, H., 2015. Implementasi Sistem Akuntansi Pemerintahan Dalam Mewujudkan Good Government Governance Pada Pemerintah Provinsi Sulawesi Utara.Volume 15.Nomor 05. Jurnal Berkala Ilmiah Efisiensi. FEB UNSRAT: Manado.

Sita, S I., 2015.Analisis Perlakuan Akuntansi Aset Tetap Pada Rumah Sakit Umum Daerah Genteng. Skripsi. Fakultas Ekonomi. Universitas Jember: Jember.

Sudaryati, Dian, 2013. Evaluasi Perlakuan Akuntansi Aset Tetap PSAP No, 07 Pada Dinas Pendapatan Pengelolaan Keuangan dan Aset Daerah Kota Tangerang Selatan. Skripsi. Jurusan Akuntansi. Fakultas Ekonomi. Universitas Pamulang: Tangerang Selatan.

Sugiyono, 2009.Metode Penelitian Pendidikan: Pendekatan Kuantitatif, Kualitatif dan R\&D. Alfabeta: Bandung.

Sunyoto, D., 2013.Metodologi Penelitian Akuntansi. Cetakan Kesatu. Refika Aditama: Bandung.

Tobari, 2015.Membangun Budaya Organisasi Pada Instansi Pemerintahan. Edisi 1.Cetakan 2.Deepublish: Yogyakarta.

Widi, Restu Kartiko, 2010. Asas Metodologi Penelitian Sebuah Pengamatan Pengenalan Penelitian. Graha Ilmu: Yogyakarta.

Wiratna, S., 2015.Akuntansi Sektor Publik. Penerbit Pustaka Baru Press: Yogyakarta.

Komite Standar Akuntansi Pemerintahan, Buletin Teknis Standar Akuntansi Pemerintahan Nomor 15 Akuntansi Aset Tetap Berbasis Akrual.

2014. Materi Pelatihan Akuntansi Keuangan Pemerintah Daerah dan SKPD. Kementerian Keuangan Republik Indonesia, Direktorat Jenderal Perimbangan Keuangan.

Peraturan Menteri No.71 Tahun 2010, Standar Akuntansi Pemerintah Berbasis Akrual, Akuntansi Aset Tetap.Lampiran I.08 PSAP No.7.

Peraturan Menteri Dalam Negeri Republik Indonesia Nomor 64 Tahun 2013, Penerapan Standar

Akuntansi Pemerintahan Berbasis Akrual Pada Pemerintah Daerah. 